\title{
HFE gene mutations in susceptibility to childhood leukemia: HuGE review
}

\author{
M. Tevfik Dorak, MD, $P h D^{1}$, Alan K. Burnett, $M D^{2}$, and Mark Worwood, $P h D^{2}$
}

\begin{abstract}
The hereditary hemochromatosis (HHC) gene, HFE on chromosome 6p21.3, encodes a protein involved in iron homeostasis. HFE mutations have low penetrance with a mild effect on serum iron levels. Animal, twin, and population studies have shown that carrier state for $\mathrm{C} 282 \mathrm{Y}$ can increase iron levels. A proportion of heterozygotes show slightly elevated serum iron levels. Increased serum iron has been suggested to increase the risk for oxidative damage to DNA. Epidemiologic studies established a correlation between iron levels and cancer risk. Case-control studies have reported associations between HFE mutations $C 282 \mathrm{Y} / \mathrm{H63D}$ and several cancers, some of which in interaction with the transferrin receptor gene TFRC or dietary iron intake. Increased cancer risk in C282Y carriers is likely due to higher iron levels in a multifactorial setting. In childhood acute lymphoblastic leukemia (ALL), there is an association of $C 282 Y$ with a gender effect in two British populations. No association has been found in acute myeloblastic leukemia and Hodgkin disease in adults. The childhood leukemia association possibly results from elevated intracellular iron in lymphoid cells increasing the vulnerability to DNA damage at a critical time window during lymphoid cell development. Interactions of HFE with environmental and genetic factors, most of which are recognized, may play a role in modification of susceptibility to leukemia conferred by $C 282 Y$. Given the population frequency of $\mathrm{C} 282 \mathrm{Y}$ and the connection between iron and cancer, clarification of the mechanism of HFE associations in leukemia and cancer will have strong implications in public health. Genet Med 2005:7(3):159168.
\end{abstract}

Key Words: HFE gene polymorphism, hereditary hemochromatosis, leukemia, Hodgkin disease, cancer, epidemiology

Hereditary hemochromatosis (HHC) is a common autosomal recessive iron overload disease (OMIM 235200). ${ }^{1}$ Because iron accumulation in vital organs and subsequent damage takes a long time, the clinical onset is usually at or after middle age. Traditionally, the disease has been diagnosed by assessment of the biochemical iron parameters (serum iron and ferritin levels, transferrin saturation). The gene responsible for the majority of HHC cases has been identified as the HFE gene on chromosome $6 \mathrm{p} 21.3 .^{2}$ The use of molecular testing in predictive diagnosis has been problematic because of the lack of strong phenotype-genotype correlation. ${ }^{1,3-6}$

Recent efforts have defined genetic heterogeneity for hereditary forms of iron overload and identified most of the genes responsible. ${ }^{7,8}$ Besides autosomal recessive classic HHC, other forms of hereditary iron overload exist (Table 1). The features

\footnotetext{
From the ${ }^{1}$ School of Clinical Medical Sciences, University of Newcastle upon Tyne, Newcastle upon Tyne, UK; and the ${ }^{2}$ Department of Haematology, School of Medicine, Wales College of Medicine, Cardiff University, Heath Park, Cardiff, UK.

M. Tevfik Dorak, MD, PhD, School of Clinical Medical Sciences, University of Newcastle upon Tyne, Sir James Spence Institute of Child Health Level 4, Royal Victoria Infirmary, Newcastle upon Tyne, UK.

Received: November 29, 2004.

Accepted: December 8, 2004.
}

DOI: 10.1097/01.GIM.0000156532.04648.81 and molecular genetics of non-HFE hemochromatosis are reviewed elsewhere. $^{7-9}$ The genes responsible for African (OMIM 601195) and neonatal (OMIM 231100) iron overload are still unknown (neonatal iron overload may be an alloimmune condition rather than genetic ${ }^{10}$ ). The importance of the genetic heterogeneity is that it may have caused misclassification error and, subsequently, some of the discrepancies in phenotype-genotype correlation in earlier HHC research.

Low penetrance of $C 282 Y$ in causation of clinical $\mathrm{HHC}$ has been established by linkage ${ }^{30}$ and molecular studies ${ }^{3-5,31-37}$ (see review $\left.^{6}\right)$. Specifically, some population-based mass screenings have shown that $<1 \%$ of homozygotes develop frank clinical hemochromatosis. ${ }^{35-37}$ It may be that expression of $C 282 Y$ as a clinical disorder requires the participation of other genes or environmental factors.

\section{GENE VARIANTS}

Originally, two missense alterations were identified in the HFE gene that occur at high frequencies in HHC patients and in the general population: a $\mathrm{G}$ to an $\mathrm{A}$ at nucleotide 845 of the original mRNA sequence (GI:1469789) in the amino acid codon 282 in exon 4 (C282Y), and a C to a G at nucleotide 187 in the same sequence in the amino acid codon 63 in exon 2 (H63D). A third missense mutation in exon 2 (nucleotide 193 
Table 1

Genes involved in regulation of body iron content

\begin{tabular}{|c|c|c|c|c|}
\hline Gene & $\begin{array}{c}\text { Gene symbol } \\
\text { (GeneID) }\end{array}$ & Map position & Disease (OMIM no.) & References \\
\hline Hemochromatosis & HFE (3077) & $6 \mathrm{p} 21.3$ & Hereditary hemochromatosis (235200) & 11 \\
\hline Hemojuvelin & $H F E 2^{a}(148738)$ & $1 \mathrm{q} 21.2$ & Juvenile hemochromatosis A (HFE2A; 602390) & 12,13 \\
\hline Hepcidin & HAMP (57817) & $19 q 13.1$ & Juvenile hemochromatosis B (HFE2B; 606464) & $14-17$ \\
\hline Transferrin receptor-2 & TFR2 (7036) & $7 \mathrm{q} 22$ & Hemochromatosis type 3 (HFE3; 604250) & 18 \\
\hline Solute carrier family 40 (Ferroportin 1) & $S C L 40 A 1^{b}(30061)$ & $2 q 32$ & Hemochromatosis type 4 (HFE4; 606069) & 19,20 \\
\hline Ferritin heavy chain 1 & FTH1 (397030) & $11 \mathrm{q} 13$ & Familial iron overload (134770) & 21 \\
\hline Transferrin & $T F(7018)$ & $3 q 22.1$ & See OMIM $190000^{c, d}$ & 22 \\
\hline Ceruloplasmin (Ferroxidase) & $C P(1356)$ & $3 q 23-q 25$ & See OMIM $117700^{c, e}$ & 23 \\
\hline Transferrin receptor- 1 & TFRC (7037) & $3 q 26.2$-qter & See OMIM 190010 & 23 \\
\hline Haptoglobin & $H P(3240)$ & $16 \mathrm{q} 22.1$ & See OMIM 140100 & 23 \\
\hline
\end{tabular}

${ }^{a}$ This gene name does not conform to the conventions because hemojuvelin gene is not related to HFE; ${ }^{b}$ formerly named SLC11A3; ${ }^{c}$ atransferrinemia and aceruloplasminemia can cause iron overload; ${ }^{d}$ the $\mathrm{C} 2$ variant (P570S) interacts with $C 282 Y$ in Alzheimer disease susceptibility ${ }^{24} ;{ }^{e}$ S142G polymorphism interacts with $\mathrm{C} 282 \mathrm{Y}$ in genetic associations with cancer susceptibility ${ }^{25-27}$ but no effect on HHC. ${ }^{28}$ Functionally important mutations of iron storage disease genes are reviewed elsewhere. ${ }^{29}$

in the mRNA sequence), $S 65 C$, has recently been identified that may contribute to the development of a mild form of HHC. ${ }^{38,39}$ Adherence to the above nucleotide numbers in description of these mutations is common practice but conflicts with the current principles of nomenclature. Acceptable unequivocal description of these three HFE mutations is shown in Table 2.

The total number of HFE variants detected to date is at least 37, of which 19 are missense ${ }^{11,29}$ (see also The Human Gene Mutation Database). The most common mutation is C282Y. The cysteine at position 282 within the immunoglobulin domain constant region takes part in a critical disulfide bond. The $\mathrm{C} 282 \mathrm{Y}$ mutation abolishes cell surface expression by preventing the association of the HFE gene product with beta- 2 microglobulin..$^{40}$ The second most common mutation H63D results in measurable consequences on hepatic iron levels in mice ${ }^{41}$ but does not cause HHC even in homozygous form in humans because of low penetrance and delayed action. ${ }^{34,42,43}$ In combination with a trans $C 282 Y$ mutation, however, $H 63 D$ can cause HHC. ${ }^{42}$ The compound heterozygosity for $\mathrm{C} 282 \mathrm{Y}$

Table 2

Three most common HFE sequence variants

\begin{tabular}{lccc}
\hline $\begin{array}{l}\text { Amino acid } \\
\text { change }\end{array}$ & $\begin{array}{c}\text { Nucleotide } \\
\text { change }^{a}\end{array}$ & dbSNP no. & $\begin{array}{c}\text { Recommended } \\
\text { nomenclature }^{b}\end{array}$ \\
\hline H63D & 3511C $>$ G & rs1799945:C $>$ G & NT_007592.13:g.3732C $>$ G \\
S65C & 3517A $>$ T & rs1800730:A $>$ T & NT_007592.13:g.3738A $>$ T \\
C282Y & 5473G $>$ A & rs1800562:G $>$ A & NT_007592.13:g.5694G $>$ A \\
\hline
\end{tabular}

${ }^{a}$ Nucleotide numbering is from the translation initiation site. Reference sequence is NT 007592.13 (GI:29804415) in which the nucleotide 222 is the first nucleotide of the first codon ATG; ${ }^{b}$ as recommended by Human Genome Variation Society (see Nomenclature for the Description of Sequence Variations). A fuller list of HFE mutations and their functional correlations are listed elsewhere. ${ }^{11,29}$ and $H 63 D$ shows its effect on iron parameters at a level between C282Y homozygosity and C282Y heterozygosity. ${ }^{34,44,45}$ The C282Y mutation causes HHC as a result of a deficiency of the HFE protein (loss-of-function) not by changing its function (gain-of-function) or cellular location. There is no sign of haploinsufficiency caused by heterozygous $C 282 Y$ mutation. ${ }^{43}$

Toomajian and Kreitman ${ }^{46}$ have conducted a comprehensive study of variation of the HFE gene on 60 chromosomes from three continents. They found a total of 41 polymorphic sites forming 18 distinct haplotypes in the 11,214-bp region including the flanking regions. Some of these polymorphic sites are in the 3' untranslated region of the gene and could conceivably affect mRNA stability or levels of protein translation. Other known polymorphisms in the $5^{\prime}$ flanking region ${ }^{47}$ or in intron $3^{48}$ do not influence serum iron indices. Functionally important mutations of HFE and other iron-related genes have been listed in a recent publication..$^{29}$

A number of genotyping methods have been used to type HFE variants. The most popular method is polymerase chain reaction-restriction fragment length polymorphism (PCRRFLP) analysis. ${ }^{49}$ A multiplex PCR-RFLP method can type the two most common mutations in a single assay. ${ }^{50} \mathrm{~A}$ comprehensive diagnostic assay for nonsynonymous changes in HFE and mutations in some of the other iron metabolism regulatory genes using PCR-sequence specific primer (PCR-SSP) method has been developed. ${ }^{11}$ Kits for exhaustive HFE typings using reverse hybridization-based strip assay are available. ${ }^{51}$ Other methods include real-time PCR, ${ }^{52}$ SSCP, ${ }^{53}$ heteroduplex analysis, ${ }^{54}$ and denaturing HPLC. ${ }^{55}$

\section{POPULATION FREQUENCIES}

Population frequencies of HFE gene variants for geographic regions and ethnic groups have been presented in another 
HuGE review ${ }^{1}$ and in more recent reports. ${ }^{34,56}$ In brief, the C282Y mutation is confined to populations of European origin and is most common in Northern Europe where the heterozygote frequency is $10 \%$ to $20 \% .{ }^{57}$

\section{DISEASE}

Childhood leukemias are rare diseases. Only 1 in 100 new cancers is a childhood cancer and approximately $25 \%$ of childhood cancers are leukemias. Nearly $80 \%$ of childhood leukemias are acute lymphoblastic leukemia (ALL). Childhood ALL has been associated with prenatal exposure to ionizing radiation, certain chromosomal abnormalities, infections and an aberrant immune response to them, socioeconomic status, maternal and perinatal factors, various environmental exposures, and parental occupational history, but the actual causes are largely unknown. ${ }^{58-60}$ Childhood leukemia is not inherited. It is more likely that genetic susceptibility increases the risk of an environmental exposure. ${ }^{61}$ Molecular epidemiologic studies identified a number of genetic associations, mainly with genes encoding xenobiotic and DNA repair enzymes. ${ }^{62,63}$ Another group of genes showing associations with childhood ALL are human leukocyte antigen (HLA) genes with a yet unknown biological mechanism. ${ }^{64-66}$

One of the most consistent findings in leukemia epidemiology is the increased male-to-female ratio. ${ }^{60,67}$ Some genetic association studies have also found gender-specific associations ${ }^{62,64,66}$ including the HFE association. ${ }^{68}$ It appears that males may have a lower threshold for genetic factors to exert their effect. The multifactorial threshold model for pyloric stenosis is similar in that males have a lower threshold to be affected with the disease. ${ }^{69,70}$ Why "maleness" lowers the liability threshold in leukemia is unknown but possible reasons include an epigenetic one as postulated for autism. ${ }^{71}$

\section{ASSOCIATIONS}

HFE is one of the molecules that participate in iron homeostasis. It has been postulated that its main role is in iron transport across the cell membrane including the regulation of absorption in the gastrointestinal tract. ${ }^{72}$ Wild-type HFE reduces the affinity of transferrin receptor for transferrin-bound iron, ${ }^{73}$ comigrates with it inside the cell, ${ }^{74}$ and regulates cellular uptake of iron from transferrin within endocytic compartments. ${ }^{75}$ When its expression is hampered, the interactions with transferrin receptor on the cell surface and with transferrin inside the cell do not occur and iron influx is increased. Despite these findings, it is possible that it has a more important role in controlling expression of hepcidin (encoded by HAMP), which has a regulatory role in downregulating the intestinal iron absorption, placental transport of iron, and the release of iron by macrophages. ${ }^{9,16}$

A twin study identified a considerable "additive" genetic component in body iron level regulation. Within that component, the share of HFE mutations was less than one would expect. ${ }^{76}$ The small share of HFE variation in total heritability has been confirmed in a population-based study. ${ }^{77}$ A study of sib-pairs homozygous for $C 282 Y$ showed significant variation in iron overload between siblings. ${ }^{3}$ These findings attribute a larger role to other genes involved in iron absorption, transport, and storage. Two such genes, HAMP and HFE2, have been shown to modify the expression of $C 282 Y$ homozygosity in HHC. ${ }^{13,15,17}$ The expression of C282Y mutation, in homozygous or heterozygous form, may require genetic modifiers and environmental interactions to have an effect on body iron content.

Although not usually causing HHC, heterozygosity for C282Y may also be relevant in disease susceptibility other than HHC. On average, 1 in 10 individuals in European populations may be heterozygous for the $C 282 Y$ mutation. ${ }^{1,34,49,56}$ This is a frightening frequency if carriers of this mutation are in any way vulnerable to any disease.

A study of 1058 heterozygotes ascertained from 202 pedigrees by family HLA typing revealed that serum iron and ferritin concentrations and transferrin saturation values generally overlapped with the normal range but were higher in 15\% to $25 \%$ of heterozygotes. ${ }^{78}$ Although mean transferrin saturation in $C 282 Y$ heterozygotes is only slightly elevated, the magnitude of elevation was similar to that reported as a risk factor for cancer in cohort studies. ${ }^{79}$

The findings of the study by Bulaj et al..$^{78}$ corroborate with those of other family- or population-based studies. In most studies, up to $25 \%$ of heterozygotes have minor subclinical iron status changes. ${ }^{31-34,80-88}$ In general, the population studies show a small but significant increase in transferrin saturation and a small but usually insignificant increase in serum ferritin. HFE heterozygosity has been confirmed as one of the genetic factors affecting body iron content also in a twin study. ${ }^{76}$ A meta-analysis of 14 studies concluded that $C 282 Y$ heterozygosity is associated with a 4 -fold risk of increased iron stores $(95 \%$ confidence interval $=2.9$ to 5.8 ), although the reliability of this result was low due to heterogeneity. ${ }^{44}$ In a minority of patients with $\mathrm{HHC}$, heterozygosity for $\mathrm{C} 282 \mathrm{Y}$ may even be the only mutation detectable out of the three major HFE mutations. ${ }^{31}$ An animal study showed that C282Y heterozygosity is capable of increasing iron levels. ${ }^{89}$ Another animal study noted the importance of genetic background in the expression of HFE mutations. ${ }^{90}$ Ethnicity may be a modifier in association studies because of the variation in other genes involved in iron homeostasis. To date, only one study has suggested higher penetrance for $H 63 D$ in Hispanics ${ }^{5}$ but this finding needs replication. The overall conclusion is that heterozygosity for the C282Y mutation of HFE may increase serum iron levels in a subset of carriers. Similar to C282Y heterozygosity, a very mild effect of $\mathrm{S} 65 \mathrm{C}$ mutation on iron overload has also been noted. ${ }^{91}$ The associations described later are most likely the result of serum iron elevation in heterozygotes.

\section{Association of iron levels with cancer}

Increased risk for cancer in subjects with even moderately elevated serum iron levels has been shown repeatedly. Prospective cohort studies including between 6,000 and 174,000 sub- 
jects have reported a link between indicators of high iron stores and increased relative risk for cancer in general.79,92-97 These studies include the first and second National Health and $\mathrm{Nu}-$ trition Examination Surveys. Additional case-control studies revealed the same link in colon ${ }^{98}$ and liver cancer. ${ }^{99,100}$ Some studies yielded negative results in gastric ${ }^{101}$ and epithelial cancers. ${ }^{102}$ The link between increased body iron and cancer was also suggested by the decreased cancer incidence in regular blood donors in Sweden. ${ }^{103}$

Increased intracellular iron can influence the process of carcinogenesis by catalyzing the formation of mutagenic hydroxyl radicals, by acting as an essential nutrient for proliferating neoplastic cells, or by its deleterious effects on the immune system. ${ }^{104-106}$ One of the immune disturbances in iron overload is the higher average $\mathrm{CD} 4: \mathrm{CD} 8$ ratios, and this is not related to the mutations in HFE but directly to iron. ${ }^{107}$ The evidence for a procarcinogenic role of iron is presented in Table 3.

As the major site of iron storage, the liver is most sensitive to iron overload. As a result, liver cancer risk secondary to cirrhosis is enormously increased in HHC and the risk is also increased in non-HHC iron overload (see Table 3). In a study of 230 patients and 230 controls with noniron-related chronic liver diseases, the increased risk for extra hepatic cancers in HHC showed no correlation with HFE genotype, indicating that it is iron itself but not HFE that confers risk for cancer. ${ }^{130}$ $\mathrm{HHC}$ is not the only oxyradical overload disease. Another hereditary disease characterized by intracellular copper overload, Wilson disease (OMIM 277900), also shows increased longterm risk with internal malignancies including hepatoma. ${ }^{131}$ Higher expression of biomarkers for oxidative stress and increased frequency of P53 tumor suppressor gene have been observed in both oxyradical overload diseases. ${ }^{132}$ More frequent spontaneous and radiation-induced chromosomal damage in $\mathrm{HHC}^{133}$ may be an important mechanism for cancer development in iron overload. Although not a uniform find-

\section{Table 3}

Evidence suggesting a procarcinogenic role for iron

\begin{tabular}{lc}
\hline Finding or observation & References \\
\hline Iron-induced oxidative DNA damage & $104,106,108-110$ \\
Iron-induced abnormalities of immune function & $107,111,112$ \\
Increased susceptibility to viral infections & 113,114 \\
$\begin{array}{l}\text { Iron as an essential nutrient for proliferating } \\
\text { neoplastic cells }\end{array}$ & $115-118$ \\
Animal experiments showing procarcinogenic & $105,116,117,119-121$ \\
$\quad$ effect of iron & $122-126$ \\
Increased liver cancer risk in HHC & $105,127,128$ \\
Increased liver cancer risk in non-HHC iron \\
$\quad$ overload \\
$\begin{array}{l}\text { Correlation between serum iron levels and } \\
\text { cancer risk }\end{array}$ \\
$\begin{array}{l}\text { Correlation between regular blood donation and } \\
\text { reduced cancer risk }\end{array}$ \\
\hline
\end{tabular}

ing, several studies reported an increased risk for extrahepatic cancer in HHC. ${ }^{124,130}$

\section{Association of HFE with leukemia and lymphoma}

An earlier study found an increased risk for cancer in obligatory heterozygotes for the putative HHC gene. ${ }^{134}$ The association with hematologic malignancies was restricted to males. After the discovery of HFE as the HHC gene, ${ }^{2}$ a number of studies have investigated $C 282 Y$ and $H 63 D$ mutations in different cancers. The first ones were conducted by Beckman et al. ${ }^{25-27}$ who found an increased frequency of C282Y mutation in multiple myeloma, breast, colorectal, and liver cancers, but only in interaction with the $S 142 G($ g. $424 A>G)$ polymorphism of TFRC. Since then, $C 282 Y$ associations have been reported in colon ${ }^{135}$ and breast cancer ${ }^{136}$ and an $H 63 D$ association in malignant glioma. ${ }^{137}$ Two studies did not find any increase in C282Y frequency in colon cancer. ${ }^{138,139}$ One study investigated the HFE mutations in a series of cancers and did not find a generally increased frequency. ${ }^{140}$ We have recently determined the $C 282 Y$ frequency in 147 cases with human immunodeficiency virus (HIV)-induced Kaposi sarcoma and their HIV and 147 human Kaposi sarcoma herpes virus (KSHV) doublepositive matched controls all from the Multicenter AIDS Cohort Study (MACS). ${ }^{141}$ We did that because of the suggestion that iron is involved in the pathogenesis of classic Kaposi sarcoma. ${ }^{142}$ The matched pair analysis by conditional logistic regression yielded an odds ratio of $5.4(95 \% \mathrm{CI}=1.8$ to $16.4 ; P=$ 0.0009 ). The mutation frequency was $14.5 \%$ in cases (all heterozygous) and $3.0 \%$ in matched-controls. It is unknown whether $C 282 Y$ is associated with cancers because of its effect on body iron content or linkage disequilibrium (LD) with another gene. The Kaposi sarcoma study also investigated the HLA complex and endothelin-1 gene (EDN1) on either side of HFE (M.T. Dorak et al., manuscript in preparation, 2005). The $C 282 Y$ association was independent of the other associations found with EDN1 and HLA genes.

HFE associations have been sought also hematologic malignancies (Table 4). We reported the $C 282 Y$ frequencies in childhood acute lymphoblastic leukemia (ALL). ${ }^{68}$ In a case-control study of Welsh and Scottish patient groups, there was an increase in $C 282 Y$ mutation frequency compared to newborns from respective newborn controls but in males only. The association mainly concerned heterozygosity for C282Y. H63D was examined only in the larger Scottish group and did not seem to contribute to leukemia susceptibility. Recent detailed work ruled out LD with EDN1 and several HLA complex loci as the reason for this association. ${ }^{143}$

There is one other published report on the $C 282 Y$ mutation in childhood leukemia from Finland. ${ }^{148}$ In a study of 232 mainly adult patients with various hematologic malignancies, 32 patients with childhood ALL (14 boys) did not have an increased frequency of $C 282 Y$. The Finnish study did not find an increased frequency in any of the subsets ( $n=15$ to 53 ). In another study of 36 Spanish patients with adult acute myeloid leukemia and 108 controls, the frequencies for $C 282 Y$ and $H 63 D$ were not different between cases and controls. ${ }^{145}$ Both 
Table 4

Associations of hematologic malignancies with $C 282 Y$

\begin{tabular}{|c|c|c|c|c|c|}
\hline Disease & $\begin{array}{l}\text { Case/control } \\
\text { numbers }\end{array}$ & Controls & $C 282 Y$ frequencies $(\%)^{a}$ & Odds ratio $(95 \% \mathrm{CI} ; P)$ & References \\
\hline Childhood ALL (Wales) & $117 / 415$ & Local newborns & 23.4 vs. $12.3^{b}$ & $2.19(1.14$ to $4.18 ; P=0.03)$ & 68 \\
\hline Childhood ALL (Scotland) & $135 / 238$ & Local newborns & 34.7 vs. $15.1^{c}$ & $2.98(1.65$ to $5.39 ; P=0.0004)$ & 68 \\
\hline Adult Hodgkin's disease (Wales) & $121 / 10556$ & Local blood donors & 11.7 vs. $15.8^{d}$ & NS & 144 \\
\hline Adult Acute Myeloid Leukemia (Spain) & $36 / 108$ & Local blood donors & 8.3 vs. 7.4 & NS & 145 \\
\hline Myelodysplastic syndrome (Hungary) & $50 / 80$ & Local blood donors & 10.0 vs. 5.0 & $2.11(0.54 \text { to } 8.27 ; \mathrm{NS})^{e}$ & 146 \\
\hline Myelodysplastic syndrome (Greece) & $54 / 264$ & Local blood donors & 0.0 vs. 0.0 & $\mathrm{NS}^{f}$ & 147 \\
\hline Hematologic malignancies (Finland) & $232 / 128$ & Local medical students & 8.2 vs. 10.2 & NS & 148 \\
\hline Hematologic malignancies (AL, USA) & $52 / 318$ & Local population controls & $0.04-0.21$ vs. 0.09 & 0.4 to $2.8(\mathrm{NS})^{g}$ & 140 \\
\hline $\begin{array}{l}\text { Hematologic malignancies (transplant } \\
\text { patients) (TN, USA) }\end{array}$ & $129 / 118$ & Local controls & 17.0 vs. 12.7 & $1.41(0.69 \text { to } 2.87 ; \mathrm{NS})^{h}$ & 136 \\
\hline
\end{tabular}

${ }^{a}$ All frequencies are marker frequencies (proportion of individuals positive for $\left.C 282 Y\right) ;{ }^{b}$ male patients only $(\mathrm{n}=64) ;{ }^{c}$ male patients only $(\mathrm{n}=75) ;{ }^{d}$ control frequency is from ref. $34{ }^{e}$ this study reported a significant increase in combined $H F E$ mutation $(C 282 Y$ and/or $H 63 D)$ frequency in patients $(52.0 \%$ vs. $31.3 \% ;$ OR $=2.38,95 \%$ $\mathrm{CI}=1.15$ to $4.94, P=0.03) ;{ }^{f}$ comparison of $H 63 D$ mutation frequencies between cases and controls yielded an OR of 1.87 (95\% CI $=0.95$ to 3.68 , Fisher's $P=$ 0.08 -our calculation); ${ }^{g}$ ORs vary for each subset with $\mathrm{n}=5$ to $13 ;{ }^{h}$ our calculation.

these studies appear to have shown negative results but obviously they were underpowered to detect significant differences. Notably, the two studies that have shown an association in childhood leukemia are British studies and to what extent this finding can be generalized to other populations is currently unknown.

Other studies of HFE associations in hematologic malignancies included our own adult Hodgkin disease case-control study, ${ }^{144}$ which revealed no association; and a myelodysplastic syndrome study in Hungary with a positive association, ${ }^{146}$ which could not be replicated in Greece. ${ }^{147}$ In the breast cancer study performed in Tennessee, the cases included patients with hematologic malignancies transplanted in the same center. ${ }^{136}$ The C282Y frequency in this subset was $17.0 \%(n=129)$ compared with local $(12.7 \%, n=118)$ and national $(12.4 \%, n=$ 2016) mutation frequencies, which appears to be increased.

All HFE-cancer association studies reported to date are casecontrol studies that have recognized limitations. Chance associations cannot be ruled out-even with replication-until functional studies identify the biological mechanism of the reported associations.

\section{Possible mechanism of leukemia association}

In other cancers associated with $C 282 Y$, statistical interactions with a TFRC allele, ${ }^{25-27}$ increased iron intake in diet and older age, ${ }^{135}$ and correlation between $C 282 Y$ gene dosage and body iron stores in breast cancer ${ }^{136}$ strongly argue that the mechanism of the HFE associations with cancer is related to iron. Thus, molecular HFE association studies seem to complement the effect of elevated iron on cancer risk. The question that whether the same risk applies to a childhood cancer has not been tested experimentally.

HFE is expressed by lymphoid as well as myeloid cells. In a B-lymphoid cell line homozygous for $C 282 Y$ and analyzed in detail, iron uptake is increased and cell sensitivity to oxidative stress is enhanced. ${ }^{149}$ This sensitivity to oxidative stress is crucial in iron-induced carcinogenesis. ${ }^{104-106,108-110}$ Chronically increased oxidative stress from elevated levels of iron in the body may increase radiation sensitivity by decreasing cellular oxygen radical scavenging capability. Low-level radiation sensitization by iron, which can occur in lymphocytes, has been proposed to increase cancer susceptibility, ${ }^{150,151}$ and heterozygosity for HFE mutations has been emphasized as a risk factor. ${ }^{152,153}$ Given the higher sensitivity to environmental exposures during early development, C282Y heterozygote fetuses, especially if their mothers are the origin of their mutation, may be subject to higher intracellular iron levels in their lymphoid cells. This may have a promoter effect if a lymphoid cell has leukemic transformation spontaneously or due to environmental exposure. Unlike adult cancers, no link has been investigated between body iron stores and childhood cancer, but in neuroblastoma, Hodgkin disease, and ALL, an unfavorable effect of increased iron stores has been shown on survival. ${ }^{154-156}$ There is a putative link between viral infection and childhood ALL. ${ }^{58,157}$ Elevated iron levels in lymphoid cells may be relevant in this context because iron favors viral infections in animals. ${ }^{113,114}$ Damage caused by iron overload in internal organs takes years, and is sex- and age-dependent. The proposed mechanism for childhood ALL entails increased intracellular iron levels in lymphoid cells during development. If iron contributes to childhood ALL susceptibility, other genes with roles in iron metabolism (Table 1) are expected to show associations. This can be investigated in incident case studies of childhood leukemia and other cancers to separate the effects of iron from a genetic association secondary to LD with $C 282 Y$ mutation.

At present, all cancer and leukemia associations with HFE are no more than statistical associations. Assuming they are real, an alternative mechanism to be explored is other genes around the HFE locus. Several candidates already exist. ${ }^{144}$ 
Among those, EDN1 is a strong one to be responsible for the C282Y association through LD. Although our preliminary study of EDN1 in childhood ALL showed a weak but independent association with no LD with $C 282 Y,{ }^{143}$ a more comprehensive study is required to rule out the involvement of neighboring genes and even other variants of $H F E$ in $C 282 Y$ association.

\section{Association of HFE with nonmalignant diseases}

Besides HHC, associations have suggested that the HFE mutations may also be involved in the development of other nonmalignant diseases. These include cardiovascular diseases, diabetes, arthritis, neurodegenerative disorders, and alcoholic liver disease. ${ }^{45,158}$ Most of these associations, however, have been inconsistent. A list of conditions showing genetic associations with HFE is being compiled at the NCBI Genetic Associations Database.

It has to be underlined that none of the disease associations suggests a uniformly deleterious effect of $C 282 Y$ mutation. If this was the case, one would expect a negative association between $C 282 Y$ and longevity. Despite an early suggestion, latest studies conclusively ruled out an age-related decline in $\mathrm{C} 282 \mathrm{Y}$ frequency. ${ }^{56,159}$ More comprehensive studies taking into account genetic and environmental interactions are needed to conclude whether a subgroup of HFE mutation carriers has higher rates of disease and what additional factors identify that subset.

\section{INTERACTIONS}

Only one gene-gene interaction, between HFE and TFRC in multiple myeloma, ${ }^{25}$ and no gene-environment interaction has been investigated in hematological malignancies. In iron overload, however, a number of factors in addition to HFE mutations affect the severity. In the most extreme example of $H f e$ knockout mice, the strain of mice determines the amount of iron in the liver. ${ }^{160} H_{A M P^{17}}$ and TFRC gene polymorphisms, ${ }^{25-27}$ mitochondrial DNA mutations, ${ }^{161}$ parent-of-origin, ${ }^{78}$ and environmental factors (including pregnancy, regular blood loss, iron intake, hepatitis B and C, and alcohol) have been suggested to interact with $C 282 Y$ in its associations with diseases or in its effect on biochemical parameters of iron stores. ${ }^{1,6,9,76,162-164}$ The P570S polymorphism of the transferrin gene shows an epistatic interaction with $C 282 Y$ as a risk marker for Alzheimer disease. ${ }^{24}$ This variant of TF has not been examined in biochemical iron overload states.

Phenotypic expression of $\mathrm{HHC}$ is affected by the presence or absence of the telomeric HLA ancestral haplotype characterized by $H L A-A^{\star} 03, D 6 S 265-1$, and D6S105-8. ${ }^{165,166}$ Patients bearing this haplotype tend to have more severe forms of $\mathrm{HHC}$, and this effect is dependent on gene dosage. ${ }^{81,167,168}$ However, this has not been a universal finding. ${ }^{169}$ Because of the effects of the ancestral haplotype on disease phenotype, HFE association studies in other diseases need to cover the area between HLA-A and HFE. This may have some bearing on the different results for the same genetic association in different populations.

\section{GAPS AND RESEARCH PRIORITIES}

Leukemia and lymphoma associations with HFE have not been sufficiently studied. Available studies are relatively small case-control studies.

\section{Definitive studies are needed}

Given the population frequency of common HFE variants and potential implications of any disease association on public health, there is need for a definitive study on HFE associations in hematopoietic cancers and especially for their mechanisms. Despite the rarity of childhood leukemias, Children's Oncology Group in USA and United Kingdom Childhood Cancer Study Group have been collecting large numbers of samples through nationwide recruitments. However, it is also important to perform association studies in other ethnic groups. Given the strong effect modification by sex, even comparison of male patients with female patients (without controls) may provide clues whether the male-specific HFE association can be confirmed in large prospective incident case studies.

\section{Other iron-related genes need to be tested}

The influence of HFE on body iron stores is small. If an iron-related mechanism is operating, variants of other genes taking part in iron homeostasis should also show associations. This is particularly important in geographic regions where $H F E$ variants have small frequencies.

\section{Possible gene-gene interactions should be addressed}

An interaction between $H F E$ and another gene in the region between HFE and HLA-A may explain the ancestral haplotype effect on HHC phenotype observed in some studies. Similarly, the HFE gene itself should be thoroughly examined especially in its regulatory regions. Interactions with the known polymorphisms of other genes such as TFRC (424A), HAMP (R59G, G71D, or R56X), and HFE2/HJV (S105L, E302K, $N 372 D, R 335 Q, L 101 P, G 320 V)$ that have an effect on iron status are important ones. No cancer association studies with HFE concurrently examined the genes encoding antioxidant enzymes. Cellular antioxidant defense mechanisms against prooxidant states include enzymes such as superoxide dismutase, catalase, and glutathione systems. ${ }^{104,170}$ Given the antipromoter and anticarcinogen activity of antioxidant defenses, ${ }^{171,172}$ deleterious effect of iron would be greater in states of reduced antioxidant reserve. The genes for these enzymes have known functional polymorphisms ${ }^{170}$ and these may also interact with HFE mutations to increase susceptibility to leukemia.

\section{Gene-environment interactions require attention}

Exposure to environmental iron during pregnancy or early childhood may interact with HFE variants in determination of leukemia susceptibility. A gene-environment interaction may also be shown with routine iron supplementation during pregnancy except when indicated for iron deficiency. In light of other genetic effect modifiers of common exposures, ${ }^{173}$ exam- 
ination of an interaction between maternal iron intake and the presence of $C 282 Y$ in the offspring may be a worthwhile effort.

\section{Parent-of-origin effect has not been studied}

The association with childhood ALL may have to do with intrauterine environment if it is due to the generally increased sensitivity of developing child (from fetus to prepuberty) to environmental assaults. ${ }^{174}$ It is a possibility that the association may be restricted to $C 282 Y$ carriers who have inherited it from their mothers and whose intrauterine environment had elevated levels of iron because of heterozygosity in mothers.

A large case-control study that would carefully construct the functionally relevant haplotypic variants of the HFE gene, examine selected other genes involved in iron metabolism with incorporation of appropriate questionnaire data on iron supplementation and dietary habits is going to be an appropriate first step to fill the gap of knowledge outlined above, especially when conducted where the evidence appears to be strongest for childhood leukemia association. A prospective family-based association study can achieve the same purpose while providing additional information on the question of parent-of-origin effect.

\section{CONCLUSIONS}

The male-specific association of $C 282 Y$ with childhood ALL in two populations seems to have generated useful hypotheses that can be tested. Currently available evidence suggests that this association with leukemia susceptibility arises from its effect on body iron levels. The sex-dependent penetrance of C282Y is age-dependent and cannot explain the male-specificity of the C282Y association in childhood. The presence of other male-specific genetic associations with childhood leukemia brings about the possibility of an additive role for these susceptibility markers over and above the risk conferred by "maleness" in a multifactorial threshold model. While what makes maleness a risk factor in genetic terms is studied, the HFE-associated susceptibility to childhood leukemia will have to be elaborated by extending the association studies to other iron-related functional genes and by taking into account gene and environment interactions. The $C 282 Y$ association in leukemia and other cancers may highlight the need to focus on the known connection between iron and cancer in which HFE plays only a limited role. The very high frequency of $C 282 Y$ in European populations does not mean that we are dealing with a problem restricted to Europe and America. If this association is due to elevated iron levels at biochemical level, the implications on the risks being inflicted by food-iron fortification programs, uncontrolled supplemental iron intake, and routine iron prescription in pregnancy will be worldwide.

\section{Electronic resources}

The following electronic resources were consulted for this review: Gene Tests (http://www.genetests.org), Kowdley et al. provide a regularly updated review of HHC and its genetics; NCBI Entrez Gene (http://www.ncbi.nlm.nih.gov/entrez/query. fcgi?db=gene) replacing NCBI LocusLink; NCBI OMIM, Online Mendelian Inheritance in Man (http://www.ncbi.nlm. nih.gov/entrez/query.fcgi? $\mathrm{db}=$ omim); NCBI Genetic Associations Database (http://geneticassociationdb.nih.gov); The Human Gene Mutation Database (Cardiff, UK) (http://archive. uwcm.ac.uk/uwcm/mg/search/119309.html); and Nomenclature for the Description of Sequence Variations (Human Genome Variation Society) (http://www.genomic.unimelb.edu.au/mdi/ mutnomen). 12-30,101-130

\section{References}

1. Hanson EH, Imperatore G, Burke W. HFE gene and hereditary hemochromatosis: a HuGE review. Human Genome Epidemiology. Am J Epidemiol 2001;154:193206.

2. Feder JN, Gnirke A, Thomas W, Tsuchihashi Z, Ruddy DA, Basava A et al. A novel MHC class I-like gene is mutated in patients with hereditary haemochromatosis. Nat Genet 1996;13:399-408.

3. Mura C, Le Gac G, Scotet V, Raguenes O, Mercier AY, Ferec C. Variation of iron loading expression in $\mathrm{C} 282 \mathrm{Y}$ homozygous haemochromatosis probands and sib pairs. J Med Genet 2001;38:632-636.

4. McCune CA, Al-Jader LN, May A, Hayes SL, Jackson HA, Worwood M. Hereditary haemochromatosis: only $1 \%$ of adult HFEC282Y homozygotes in South Wales have a clinical diagnosis of iron overload. Hum Genet 2002;111:538-543.

5. Cogswell ME, Gallagher ML, Steinberg KK, Caudill Ph DS, Looker AC, Bowman BA et al. HFE genotype and transferrin saturation in the United States. Genet Med 2003;5:304-310.

6. Beutler E. The HFE Cys282Tyr mutation as a necessary but not sufficient cause of clinical hereditary hemochromatosis. Blood 2003;101:3347-3350.

7. Pietrangelo A. Non-HFE hemochromatosis. Hepatology 2004;39:21-29.

8. Robson KJ, Merryweather-Clarke AT, Cadet E, Viprakasit V, Zaahl MG, Pointon JJ et al. Recent advances in understanding haemochromatosis: a transition state. J Med Genet 2004;41:721-730.

9. Pietrangelo A. Hereditary hemochromatosis: a new look at an old disease. $N$ Engl J Med 2004;350:2383-2397.

10. Whitington PF, Hibbard JU. High-dose immunoglobulin during pregnancy for recurrent neonatal haemochromatosis. Lancet 2004;364:1690-1698.

11. Jones DC, Young NT, Pigott C, Fuggle SV, Barnardo MC, Marshall SE, Bunce M. Comprehensive hereditary hemochromatosis genotyping. Tissue Antigens 2002;60: 481-488.

12. Lanzara C, Roetto A, Daraio F, Rivard S, Ficarella R, Simard H et al. The spectrum of hemojuvelin gene mutations in 1q-linked juvenile hemochromatosis. Blood 2004;103:4317-4321.

13. Le Gac G, Scotet V, Ka C, Gourlaouen I, Bryckaert L, Jacolot S et al. The recently identified type $2 \mathrm{~A}$ juvenile haemochromatosis gene (HJV), a second candidate modifier of the C282Y homozygous phenotype. Hum Mol Genet 2004;13:19131918.

14. Roetto A, Papanikolaou G, Politou M, Alberti F, Girelli D, Christakis J et al. Mutant antimicrobial peptide hepcidin is associated with severe juvenile hemochromatosis. Nat Genet 2003;33:21-22.

15. Merryweather-Clarke AT, Cadet E, Bomford A, Capron D, Viprakasit V, Miller A et al. Digenic inheritance of mutations in HAMP and HFE results in different types of haemochromatosis. Hum Mol Genet 2003;12:2241-2247.

16. Ganz T. Hepcidin, a key regulator of iron metabolism and mediator of anemia of inflammation. Blood 2003;102:783-788.

17. Jacolot S, Le Gac G, Scotet V, Quere I, Mura C, Ferec C. HAMP as a modifier gene that increases the phenotypic expression of the HFE pC282Y homozygous genotype. Blood 2004;103:2835-2840.

18. Camaschella C, Roetto A, Cali A, De Gobbi M, Garozzo G, Carella M et al. The gene TFR2 is mutated in a new type of haemochromatosis mapping to 7q22. Nat Genet 2000;25:14-15.

19. Njajou OT, Vaessen N, Joosse M, Berghuis B, van Dongen JW, Breuning MH et al. A mutation in SLC11A3 is associated with autosomal dominant hemochromatosis. Nat Genet 2001;28:213-214.

20. Devalia V, Carter K, Walker AP, Perkins SJ, Worwood M, May A et al. Autosomal dominant reticuloendothelial iron overload associated with a 3-base pair deletion in the ferroportin 1 gene (SLC11A3). Blood 2002;100:695-697.

21. Kato J, Fujikawa K, Kanda M, Fukuda N, Sasaki K, Takayama T et al. A mutation, in the iron-responsive element of $\mathrm{H}$ ferritin mRNA, causing autosomal dominant iron overload. Am J Hum Genet 2001;69:191-197. 
22. Lee PL, Halloran C, Beutler E. Polymorphisms in the transferrin 5' flanking region associated with differences in total iron binding capacity: possible implications in iron homeostasis. Blood Cells Mol Dis 2001;27:539-548.

23. Lee PL, Gelbart T, West C, Halloran C, Felitti V, Beutler E. A study of genes that may modulate the expression of hereditary hemochromatosis: transferrin receptor-1, ferroportin, ceruloplasmin, ferritin light and heavy chains, iron regulatory proteins (IRP)-1 and -2, and hepcidin. Blood Cells Mol Dis 2001;27:783-802.

24. Robson KJ, Lehmann DJ, Wimhurst VL, Livesey KJ, Combrinck M, MerryweatherClarke AT et al. Synergy between the C2 allele of transferrin and the C282Y allele of the haemochromatosis gene (HFE) as risk factors for developing Alzheimer's disease. J Med Genet 2004;41:261-265.

25. Van Landeghem GF, Beckman LE, Wahlin A, Markevarn B, Beckman L. Interaction between haemochromatosis and transferrin receptor genes in multiple myeloma [letter]. Lancet 1998;352:1285-1286.

26. Beckman LE, Van Landeghem GF, Sikstrom C, Wahlin A, Markevarn B, Hallmans $\mathrm{G}$ et al. Interaction between haemochromatosis and transferrin receptor genes in different neoplastic disorders. Carcinogenesis 1999;20:1231-1233.

27. Beckman LE, Hagerstrand I, Stenling R, Van Landeghem GF, Beckman L. Interaction between haemochromatosis and transferrin receptor genes in hepatocellular carcinoma. Oncology 2000;59:317-322.

28. Tsuchihashi Z, Hansen SL, Quintana L, Kronmal GS, Mapa FA, Feder JN et al. Transferrin receptor mutation analysis in hereditary hemochromatosis patients. Blood Cells Mol Dis 1998;24:317-321.

29. Beutler L, Beutler E. Hematologically important mutations: iron storage diseases. Blood Cells Mol Dis 2004;33:40-44.

30. Edwards CQ, Cartwright GE, Skolnick MH, Amos DB. Homozygosity for hemochromatosis: clinical manifestations. Ann Intern Med 1980;93:519-525.

31. Crawford DH, Jazwinska EC, Cullen LM, Powell LW. Expression of HLA-linked hemochromatosis in subjects homozygous or heterozygous for the $\mathrm{C} 282 \mathrm{Y}$ mutation. Gastroenterology 1998;114:1003-1008.

32. Olynyk JK, Cullen DJ, Aquilia S, Rossi E, Summerville L, Powell LW. A populationbased study of the clinical expression of the hemochromatosis gene. $N$ Engl J Med 1999;341:718-724.

33. Barton JC, Rothenberg BE, Bertoli LF, Acton RT. Diagnosis of hemochromatosis in family members of probands: a comparison of phenotyping and HFE genotyping. Genet Med 1999;1:89-93.

34. Jackson HA, Carter K, Darke C, Guttridge MG, Ravine D, Hutton RD et al. HFE mutations, iron deficiency and overload in 10,500 blood donors. Br J Haematol 2001;114:474-484.

35. Asberg A, Hveem K, Thorstensen K, Ellekjter E, Kannelonning K, Fjosne U et al. Screening for hemochromatosis: high prevalence and low morbidity in an unselected population of 65,238 persons. Scand J Gastroenterol 2001;36:1108-1115.

36. Beutler E, Felitti VJ, Koziol JA, Ho NJ, Gelbart T. Penetrance of 845G->A (C282Y) HFE hereditary haemochromatosis mutation in the USA. Lancet 2002;359:211218.

37. Andersen RV, Tybjaerg-Hansen A, Appleyard M, Birgens H, Nordestgaard BG. Hemochromatosis mutations in the general population: iron overload progression rate. Blood 2004;103:2914-2919.

38. Mura C, Raguenes O, Ferec C. HFE mutations analysis in 711 hemochromatosis probands: evidence for S65C implication in mild form of hemochromatosis. Blood 1999;93:2502-2505.

39. Barton JC, Sawada-Hirai R, Rothenberg BE, Acton RT. Two novel missense mutations of the HFE gene (I105T and G93R) and identification of the S65C mutation in Alabama hemochromatosis probands. Blood Cells Mol Dis 1999;25:147-155.

40. Feder JN, Tsuchihashi Z, Irrinki A, Lee VK, Mapa FA, Morikang E et al. The hemochromatosis founder mutation in HLA-H disrupts $\beta 2$-microglobulin interaction and cell surface expression. J Biol Chem 1997;272:14025-14028.

41. Tomatsu S, Orii KO, Fleming RE, Holden CC, Waheed A, Britton RS et al. Contribution of the H63D mutation in HFE to murine hereditary hemochromatosis. Proc Natl Acad Sci USA 2003;100:15788-15793.

42. Beutler E. The significance of the 187G (H63D) mutation in hemochromatosis [letter]. Am J Hum Genet 1997;61:762-764.

43. Rosmorduc O, Poupon R, Nion I, Wendum D, Feder J, Bereziat G et al. Differential HFE allele expression in hemochromatosis heterozygotes. Gastroenterology 2000; 119:1075-1086.

44. Burke W, Imperatore G, McDonnell SM, Baron RC, Khoury MJ. Contribution of different HFE genotypes to iron overload disease: a pooled analysis. Genet Med 2000;2:271-277.

45. Worwood M. HFE Mutations as risk factors in disease. Best Pract Res Clin Haematol 2002;15:295-314.

46. Toomajian C, Kreitman M. Sequence variation and haplotype structure at the human HFE locus. Genetics 2002;161:1609-1623.
47. Beutler E, West C. Polymorphisms in the 5' flanking region of the HFE gene: linkage disequilibrium and relationship to iron homeostasis. Blood Cells $\mathrm{Mol}$ Dis 2002;28:191-195

48. Beutler E, Gelbart T. A common intron 3 mutation (IVS3-48c->g) leads to misdiagnosis of the c. 845G->A (C282Y) HFE gene mutation. Blood Cells Mol Dis 2000;26:229-233.

49. Merryweather-Clarke AT, Pointon JJ, Shearman JD, Robson KJ. Global prevalence of putative haemochromatosis mutations. J Med Genet 1997;34:275-278.

50. Stott MK, Fellowes AP, Upton JD, Burt MJ, George PM. Simple multiplex PCR for the simultaneous detection of the $\mathrm{C} 282 \mathrm{Y}$ and $\mathrm{H} 63 \mathrm{D}$ hemochromatosis (HFE) gene mutations. Clin Chem 1999;45:426-428.

51. Kotze MJ, de Villiers JN, Bouwens CS, Warnich L, Zaahl MG, van der Merwe S et al Molecular diagnosis of hereditary hemochromatosis: application of a newly-developed reverse-hybridization assay in the South African population. Clin Genet 2004, 65:317-321.

52. Donohoe GG, Laaksonen M, Pulkki K, Ronnemaa T, Kairisto V. Rapid single-tube screening of the $\mathrm{C} 282 \mathrm{Y}$ hemochromatosis mutation by real-time multiplex allelespecific PCR without fluorescent probes. Clin Chem 2000;46:1540-1547.

53. Bosserhoff AK, Seegers S, Hellerbrand C, Scholmerich J, Buttner R. Rapid genetic screening for hemochromatosis using automated SSCP-based capillary electrophoresis (SSCP-CE). Biotechniques 1999;26:1106-1110.

54. Jackson HA, Bowen DJ, Worwood M. Rapid genetic screening for haemochromatosis using heteroduplex technology. Br J Haematol 1997;98:856-859.

55. Biasiotto G, Belloli S, Ruggeri G, Zanella I, Gerardi G, Corrado M et al. Identification of new mutations of the HFE, hepcidin, and transferrin receptor 2 genes by denaturing HPLC analysis of individuals with biochemical indications of iron overload. Clin Chem 2003;49:1981-1988.

56. Steinberg KK, Cogswell ME, Chang JC, Caudill SP, McQuillan GM, Bowman BA et al. Prevalance of $\mathrm{C} 282 \mathrm{Y}$ and $\mathrm{H} 63 \mathrm{D}$ mutations in the hemochromatosis (HFE) gene in the United States. JAMA 2001;285:2216-2222.

57. Merryweather-Clarke AT, Pointon JJ, Jouanolle A, Rochette J, Robson KJ. Geography of HFE C282Y and H63D mutations. Genet Test 2000;4:183-198.

58. Greaves MF. Aetiology of acute leukaemia. Lancet 1997;349:344-349.

59. Little J. Epidemiology of Childhood Cancer. AIRC Scientific Publications No. 149. Lyon, France: International Agency for Research on Cancer; 1999.

60. Linet MS, Wacholder S, Zahm SH. Interpreting epidemiologic research: lessons from studies of childhood cancer. Pediatrics 2003;112:218-232.

61. Birch JM. Genes and cancer. Arch Dis Child 1999;80:1-3.

62. Sinnett D, Krajinovic M, Labuda D. Genetic susceptibility to childhood acute lymphoblastic leukemia. Leuk Lymphoma 2000;38:447-462.

63. Krajinovic M, Labuda D, Sinnett D. Childhood acute lymphoblastic leukemia: genetic determinants of susceptibility and disease outcome. Rev Environ Health 2001;16:263-279.

64. Dorak MT, Lawson T, Machulla HKG, Darke C, Mills KI, Burnett AK. Unravelling an HLA-DR association in childhood acute lymphoblastic leukemia. Blood 1999; 94:694-700.

65. Taylor GM, Dearden S, Ravetto P, Ayres M, Watson P, Hussain A et al. Genetic susceptibility to childhood common acute lymphoblastic leukaemia is associated with polymorphic peptide-binding pocket profiles in $\mathrm{HLA}^{\mathrm{DPB}}{ }^{\star} 0201$. Hum Mol Genet 2002;11:1585-1597.

66. Dorak MT, Oguz FS, Yalman N, Diler AS, Kalayoglu S, Anak S et al. A male-specific increase in the HLA-DRB4 (DR53) frequency in high-risk and relapsed childhood ALL. Leuk Res 2002;26:651-656.

67. Cartwright RA, Gurney KA, Moorman AV. Sex ratios and the risks of haematological malignancies. Br J Haematol 2002;118:1071-1017.

68. Dorak MT, Sproul AM, Gibson BE, Burnett AK, Worwood M. The C282Y mutation of HFE is another male-specific risk factor for childhood ALL. Blood 1999;94 3957-3958.

69. Chakraborty R. The inheritance of pyloric stenosis explained by a multifactorial threshold model with sex dimorphism for liability. Genet Epidemiol 1986;3:1-15.

70. Jorde LB, Carey JC, Bamshad MJ, White RL. Medical Genetics, 3rd ed. St. Louis, Mo: Mosby; 2003.

71. Skuse DH. Imprinting, the $\mathrm{X}$-chromosome, and the male brain: explaining sex differences in the liability to autism. Pediatr Res 2000;47:9-16.

72. Morgan EH, Oates PS. Mechanisms and regulation of intestinal iron absorption. Blood Cells Mol Dis 2002;29:384-399.

73. Feder IN, Penny DM, Irrinki A, Lee VK, Lebron JA, Watson $\mathrm{N}$ et al. The hemochromatosis gene product complexes with the transferrin receptor and lowers its affinity for ligand binding. Proc Natl Acad Sci USA 1998;95:1472-1477.

74. Gross CN, Irrinki A, Feder JN, Enns CA. Co-trafficking of HFE, a nonclassical major histocompatibility complex class I protein, with the transferrin receptor implies a role in intracellular iron regulation. J Biol Chem 1998;273:22068-22074. 
75. Feeney GP, Worwood M. The effects of wild-type and mutant HFE expression upon cellular iron uptake in transfected human embryonic kidney cells. Biochim Biophys Acta 2001;1538:242-251.

76. Whitfield JB, Cullen LM, Jazwinska EC, Powell LW, Heath AC, Zhu G et al. Effects of HFE C282Y and H63D polymorphisms and polygenic background on iron stores in a large community sample of twins. Am J Hum Genet 2000;66:1246-1258.

77. Njajou OT, Houwing-Duistermaat JJ, Osborne RH, Vaessen N, Vergeer J, Heeringa J et al. A population-based study of the effect of the HFE C282Y and H63D mutations on iron metabolism. Eur J Hum Genet 2003;11:225-231.

78. Bulaj ZJ, Griffen LM, Jorde LB, Edwards CQ, Kushner JP. Clinical and biochemical abnormalities in people heterozygous for hemochromatosis. N Engl J Med 1996; 335:1799-1805.

79. Stevens RG, Graubard BI, Micozzi MS, Neriishi K, Blumberg BS. Moderate elevation of body iron level and increased risk of cancer occurrence and death. Int J Cancer 1994;56:364-369.

80. Adams PC. Prevalence of abnormal iron studies in heterozygotes for hereditary hemochromatosis: an analysis of 255 heterozygotes. Am J Hematol 1994;45:146149.

81. Crawford D, Powell L, Leggett B, Francis J, Fletcher L, Webb S et al. Evidence that the ancestral haplotype in Australian hemochromatosis patients may be associated with a common mutation in the gene. Am J Hum Genet 1995;57:362-367.

82. Datz C, Haas T, Rinner H, Sandhofer F, Patsch W, Paulweber B. Heterozygosity for the $\mathrm{C} 282 \mathrm{Y}$ mutation in the hemochromatosis gene is associated with increased serum iron, transferrin saturation, and hemoglobin in young women: a protective role against iron deficiency? Clin Chem 1998;44:2429-2432.

83. Distante S, Berg JP, Lande K, Haug E, Bell H. High prevalence of the hemochromatosis-associated Cys282Tyr HFE gene mutation in a healthy Norwegian population in the city of Oslo, and its phenotypic expression. Scand J Gastroenterol 1999;34:529-534.

84. Beutler E, Felitti V, Gelbart T, Ho N. The effect of HFE genotypes on measurements of iron overload in patients attending a health appraisal clinic. Ann Intern Med 2000;133:329-337.

85. de Valk B, Witlox RS, van der Schouw YT, Marx JJ. Biochemical expression of heterozygous hereditary hemochromatosis. Eur J Intern Med 2000;11:317-321.

86. Cassanelli S, Pignatti E, Montosi G, Garuti C, Mariano M, Campioli D et al. Frequency and biochemical expression of C282Y/H63D hemochromatosis (HFE) gene mutations in the healthy adult population in Italy. J Hepatol 2001;34:523-528.

87. McLaren CE, Li KT, Garner CP, Beutler E, Gordeuk VR. Mixture distribution analysis of phenotypic markers reflecting HFE gene mutations. Blood 2003;102: 4563-4566.

88. Beutler E, Felitti V, Gelbart T, Waalen J. Haematological effects of the C282Y HFE mutation in homozygous and heterozygous states among subjects of northern and southern European ancestry. Br J Haematol 2003;120:887-893.

89. Levy JE, Montross LK, Cohen DE, Fleming MD, Andrews NC. The C282Y mutation causing hereditary hemochromatosis does not produce a null allele. Blood 1999;94:9-11.

90. Fleming RE, Holden CC, Tomatsu S, Waheed A, Brunt EM, Britton RS et al. Mouse strain differences determine severity of iron accumulation in Hfe knockout model of hereditary hemochromatosis. Proc Natl Acad Sci USA 2001;98:2707-2711.

91. Holmstrom P, Marmur J, Eggertsen G, Gafvels M, Stal P. Mild iron overload in patients carrying the HFE S65C gene mutation: a retrospective study in patients with suspected iron overload and healthy controls. Gut 2002;51:723-730.

92. Stevens RG, Jones DY, Micozzi MS, Taylor PR. Body iron stores and the risk of cancer. N Engl J Med 1988;319:1047-1052.

93. Selby JV, Friedman GD. Epidemiologic evidence of an association between body iron stores and risk of cancer. Int J Cancer 1988;41:677-682.

94. Knekt P, Reunanen A, Takkunen H, Aromaa A, Heliavaara M, Hakulinen T. Body iron stores and risk of cancer. Int J Cancer 1994;56:379-382.

95. van Asperen IA, Feskens EJ, Bowles CH, Kromhout D. Body iron stores and mortality due to cancer and ischaemic heart disease: a 17-year follow-up study of elderly men and women. Int J Epidemiol 1995;24:665-670.

96. Lee DH, Anderson KE, Harnack LJ, Folsom AR, Jacobs DR Jr. Heme iron, zinc, alcohol consumption, and colon cancer: Iowa Women's Health Study. J Natl Cancer Inst 2004;96:403-407.

97. Wu T, Sempos CT, Freudenheim JL, Muti P, Smit E. Serum iron, copper and zinc concentrations and risk of cancer mortality in US adults. Ann Epidemiol 2004;14: 195-201

98. Nelson RL, Davis FG, Sutter E, Sobin LH, Kikendall JW, Bowen P. Body iron stores and risk of colonic neoplasia. J Natl Cancer Inst 1994;86:455-460.

99. Hann HW, Kim CY, London WT, Blumberg BS. Increased serum ferritin in chronic liver disease: a risk factor for primary hepatocellular carcinoma. Int J Cancer 1989;43:376-379.
100. Hellerbrand C, Poppl A, Hartmann A, Scholmerich J, Lock G. HFE C282Y heterozygosity in hepatocellular carcinoma: evidence for an increased prevalence. Clin Gastroenterol Hepatol 2003;1:279-284.

101. Akiba S, Neriishi K, Blot WJ, Kabuto M, Stevens RG, Kato H, Land CE. Serum ferritin and stomach cancer risk among a Japanese population. Cancer 1991;67: 1707-1712.

102. Herrinton LJ, Friedman GD, Baer D, Selby JV. Transferrin saturation and risk of cancer. Am J Epidemiol 1995;142:692-698.

103. Merk K, Mattsson B, Mattsson A, Holm G, Gullbring B, Bjorkholm M. The incidence of cancer among blood donors. Int J Epidemiol 1990;19:505-509.

104. Toyokuni S. Iron-induced carcinogenesis: the role of redox regulation. Free Radic Biol Med 1996;20:553-566.

105. Deugnier Y, Turlin B, Loreal O. Iron and neoplasia. Hepatology 1998;28:21-25.

106. Huang X. Iron overload and its association with cancer risk in humans: evidence for iron as a carcinogenic metal. Mutat Res 2003;533:153-171.

107. de Sousa M, Porto G. The immunological system in hemochromatosis. Hepatology 1998;28:1-7.

108. McCord JM. Iron, free radicals, and oxidative injury. Semin Hematol 1998;35:5-12.

109. Kawanishi S, Hiraku Y, Murata M, Oikawa S. The role of metals in site-specific DNA damage with reference to carcinogenesis. Free Radic Biol Med 2002;32:822832

110. Eaton JW, Qian M. Molecular bases of cellular iron toxicity. Free Radic Biol Med 2002;32:833-840.

111. Good MF, Powell LW, Halliday JW. Iron status and cellular immune competence. Blood Rev 1988;2:43-49.

112. Walker EM, Walker SM. Effects of iron overload on the immune system. Ann Clin Lab Sci 2000;30:354-365.

113. Weinberg ED. Iron withholding: a defense against viral infections. Biometals 1996; 9:393-399.

114. Weinberg ED. Iron and susceptibility to infectious disease. Science 1974;184:952956.

115. Hann HW, Stahlhut MW, Blumberg BS. Iron nutrition and tumor growth: decreased tumor growth in iron-deficient mice. Cancer Res 1988;48:4168-4170.

116. Hann HW, Stahlhut MW, Menduke H. Iron enhances tumor growth. Observation on spontaneous mammary tumors in mice. Cancer 1991;68:2407-2410.

117. Siegers CP, Bumann D, Trepkau HD, Schadwinkel B, Baretton G. Influence of dietary iron overload on cell proliferation and intestinal tumorigenesis in mice. Cancer Lett 1992;65:245-249.

118. Le NT, Richardson DR. The role of iron in cell cycle progression and the proliferation of neoplastic cells. Biochim Biophys Acta 2002;1603:31-46.

119. Singh M, Lu J, Briggs SP, McGinley JN, Haegele AD, Thompson HJ. Effect of exces dietary iron on the promotion stage of 1-methyl-1-nitrosourea-induced mammary carcinogenesis: pathogenetic characteristics and distribution of iron. Carcinogenesis 1994;15:1567-1570.

120. Deguchi J, Miyamoto M, Okada S. Sex hormone-dependent renal cell carcinogenesis induced by ferric nitrilotriacetate in Wistar rats. Jpn J Cancer Res 1995;86: $1068-1071$

121. Ma Y, Kawabata T, Hamazaki S, Ogino T, Okada S. Sex differences in oxidative damage in ddY mouse kidney treated with a renal carcinogen, iron nitrilotriacetate. Carcinogenesis 1998;19:1983-1988.

122. Niederau C, Fischer R, Sonnenberg A, Stremmel W, Trampisch HJ, Strohmeyer G. Survival and causes of death in cirrhotic and in noncirrhotic patients with primary hemochromatosis. N Engl J Med 1985;313:1256-1262.

123. Bradbear RA, Bain C, Siskind V, Schofield FD, Webb S, Axelsen EM et al. Cohort study of internal malignancy in genetic hemochromatosis and other chronic nonalcoholic liver diseases. J Natl Cancer Inst 1985;75:81-84

124. Fargion S, Mandelli C, Piperno A, Cesana B, Fracanzani AL, Fraquelli M et al Survival and prognostic factors in 212 Italian patients with genetic hemochromatosis. Hepatology 1992;15:655-659.

125. Hsing AW, McLaughlin JK, Olsen JH, Mellemkjaer L, Wacholder S, Fraumeni JF Jr. Cancer risk following primary hemochromatosis: A population-based cohort study in Denmark. Int J Cancer 1995;60:160-162.

126. Elmberg M, Hultcrantz R, Ekbom A, Brandt L, Olsson S, Olsson R et al. Cancer risk in patients with hereditary hemochromatosis and in their first-degree relatives. Gastroenterology 2003;125:1733-1741.

127. Turlin B, Juguet F, Moirand R, Le Quilleuc D, Loreal O, Campion JP et al. Increased liver iron stores in patients with hepatocellular carcinoma developed on a noncirrhotic liver. Hepatology 1995;22:446-450.

128. Mandishona E, MacPhail AP, Gordeuk VR, Kedda MA, Paterson AC, Rouault TA et al. Dietary iron overload as a risk factor for hepatocellular carcinoma in Black Africans. Hepatology 1998;27:1563-1566.

129. Herbert V, Shaw S, Jayatilleke E, Stopler-Kasdan T. Most free-radical injury is iron-related: it is promoted by iron, hemin, holoferritin and vitamin C, and inhibited by desferoxamine and apoferritin. Stem Cells 1994;12:289-303. 


\section{Dorak et al.}

130. Fracanzani AL, Conte D, Fraquelli M, Taioli E, Mattioli M, Losco A et al. Increased cancer risk in a cohort of 230 patients with hereditary hemochromatosis in comparison to matched control patients with non-iron-related chronic liver disease. Hepatology 2001;33:647-651.

131. Walshe JM, Waldenstrom E, Sams V, Nordlinder H, Westermark K. Abdominal malignancies in patients with Wilson's disease. QJM 2003;96:657-662.

132. Hussain SP, Raja K, Amstad PA, Sawyer M, Trudel LJ, Wogan GN et al. Increased p53 mutation load in nontumorous human liver of Wilson disease and hemochromatosis: oxyradical overload diseases. Proc Natl Acad Sci USA 2000;97:1277012775 .

133. Nordenson I, Ritter B, Beckman A, Beckman L. Idiopathic hemochromatosis and chromosomal damage. Human Heredity 1992;42:143-145.

134. Nelson RL, Davis FG, Persky V, Becker E. Risk of neoplastic and other diseases among people with heterozygosity for hereditary hemochromatosis. Cancer 1995; 76:875-879.

135. Shaheen NJ, Silverman LM, Keku T, Lawrence LB, Rohlfs EM et al. Association between hemochromatosis (HFE) gene mutation carrier status and the risk of colon cancer. J Natl Cancer Inst 2003;95:154-159.

136. Kallianpur AR, Hall LD, Yadav M, Christman BW, Dittus RS, Haines JL et al Increased prevalence of the HFE C282Y hemochromatosis allele in women with breast cancer. Cancer Epidemiol Biomarkers Prev 2004;13:205-212.

137. Martinez di Montemuros F, Tavazzi D, Salsano E, Piepoli T, Pollo B, Fiorelli G et al High frequency of the H63D mutation of the hemochromatosis gene (HFE) in malignant gliomas. Neurology 2001;57:1342

138. Macdonald GA, Tarish J, Whitehall VJ, McCann SJ, Mellick GD, Buttenshaw RL et al. No evidence of increased risk for colorectal cancer in individuals heterozygous for the Cys282Tyr haemochromatosis mutation. J Gastroenterol Hepatol 1999;14: $1188-1191$.

139. Altes A, Gimferrer E, Capella G, Barcelo MJ, Baiget M. Colorectal cancer and HFE gene mutations. Haematologica 1999;84:479-480.

140. Barton JC, Bertoli LF, Acton RT. HFE C282Y and H63D in adults with malignancies in a community medical oncology practice. BMC Cancer 2004;4:6.

141. Dorak MT, Shao W, Lobashevsky ES, Tang J, Kaslow RA. The C282Y mutation of HFE is a risk factor for HIV-related Kaposi's sarcoma [Abstract]. Hum Immunol 2003;64:S145.

142. Simonart T. Iron: a target for the management of Kaposi's sarcoma? BMC Cancer 2004;4:1.

143. Dorak MT, Relton CL, Hammal D, Hall AG, Parker L. HFE-C282Y association in childhood ALL: Pointing towards iron? Children with Leukaemia Conference, London, Sept 6-10, 2004.

144. Dorak MT, Burnett AK, Worwood M. Hemochromatosis gene in leukemia and lymphoma. Leuk Lymphoma 2002;43:467-477.

145. Gimferrer E, Nomdedeu J, Gich I, Barcelo MJ, Baiget M. Prevalence of hemochromatosis related HFE gene mutations in patients with acute myeloid leukemia [letter]. Leuk Res 1999;23:597-598.

146. Varkonyi J, Tarkovacs G, Karadi I, Andrikovics H, Varga F, Demeter J et al. High incidence of hemochromatosis gene mutations in the myelodysplastic syndrome: the Budapest Study on 50 patients. Acta Haematol 2003;109:64-67.

147. Speletas M, Kioumi A, Mandala E, Katodritou E, Papaioannou G, Ritis K et al. Prevalence of hemochromatosis gene (HFE) mutations in Greek patients with myelodysplastic syndromes. Acta Haematol 2003;110:53-54.

148. Hannuksela J, Savolainen ER, Koistinen P, Parkkila S. Prevalence of HFE genotypes, $\mathrm{C} 282 \mathrm{Y}$ and $\mathrm{H} 63 \mathrm{D}$, in patients with hematologic disorders. Haematologica 2002;87:131-135.

149. Chitambar CR, Wereley JP. Iron transport in a lymphoid cell line with the hemochromatosis C282Y mutation. Blood 2001;97:2734-2740.

150. Stevens RG, Kalkwarf DR. Iron, radiation, and cancer. Environ Health Perspect 1990;87:291-300.

151. Nelson JM, Stevens RG. Ferritin-iron increases killing of Chinese hamster ovary cells by X-irradiation. Cell Prolif 1992;25:579-585.
152. Stevens RG, Morris JE, Anderson LE. Hemochromatosis heterozygotes may constitute a radiation-sensitive subpopulation. Radiat Res 2000;153:844-847.

153. Stevens RG. Hemochromatosis heterozygotes may constitute a radiation-sensitive subpopulation. Radiat Res 2000;154:725-727.

154. Potaznik D, Groshen S, Miller D, Bagin R, Bhalla R, Schwartz M et al. Association of serum iron, serum transferrin saturation, and serum ferritin with survival in acute lymphocytic leukemia. Am J Ped Hematol Oncol 1987;9:350-355.

155. Evans AE, D’Angio GJ, Propert K, Anderson J, Hann HW. Prognostic factor in neuroblastoma. Cancer 1987;59:1853-1859.

156. Hann HW, Lange B, Stahlhut MW, McClynn KA. Prognostic importance of serum transferrin and ferritin in childhood Hodgkin's disease. Cancer 1990;66:313-316.

157. Kinlen LJ. Epidemiological evidence for an infective basis in childhood leukaemia. Br J Cancer 1995;71:1-5.

158. Fuchs J, Podda M, Packer L, Kaufmann R. Morbidity risk in HFE associated he reditary hemochromatosis C282Y heterozygotes. Toxicology 2002;180:169-181.

159. Coppin H, Bensaid M, Fruchon S, Borot N, Blanche H, Roth MP. Longevity and carrying the $\mathrm{C} 282 \mathrm{Y}$ mutation for haemochromatosis on the HFE gene: case control study of 492 French centenarians. BMJ 2003;327:132-133.

160. Levy JE, Montross LK, Andrews NC. Genes that modify the hemochromatosis phenotype in mice. J Clin Invest 2000;105:1209-1216.

161. Livesey KJ, Wimhurst VL, Carter K, Worwood M, Cadet E, Rochette J et al. The 16189 variant of mitochondrial DNA occurs more frequently in C282Y homozygotes with haemochromatosis than those without iron loading. J Med Genet 2004; 41:6-10

162. Burke W, Press N, McDonnell SM. Hemochromatosis: genetics helps to define a multifactorial disease. Clin Genet 1998;54:1-9.

163. Fargion S, Stazi MA, Fracanzani AL, Mattioli M, Sampietro M, Tavazzi D et al Mutations in the HFE gene and their interaction with exogenous risk factors in hepatocellular carcinoma. Blood Cells Mol Dis 2001;27:505-511.

164. Scotet V, Merour MC, Mercier AY, Chanu B, Le Faou T, Raguenes O et al. Hereditary hemochromatosis: effect of excessive alcohol consumption on disease expression in patients homozygous for the C282Y mutation. Am J Epidemiol 2003;158: $129-134$.

165. Worwood M, Raha-Chowdhury R, Dorak MT, Darke C, Bowen DJ, Burnett AK. Alleles at D6S265 and D6S105 define a haemochromatosis-specific genotype. $\mathrm{Br} J$ Haematol 1994;86:863-866.

166. Worwood M, Dorak MT, Raha-Chowdhury R. Haplotypes in linkage disequilibrium with the hemochromatosis gene [letter]. Am J Hum Genet 1994;55:585-586.

167. Piperno A, Arosio C, Fargion S, Roetto A, Nicoli C, Girelli D et al. The ancestral hemochromatosis haplotype is associated with a severe phenotype expression in Italian patients. Hepatology 1996;24:43-46.

168. Barton JC, Shih WW, Sawada-Hirai R, Acton RT, Harmon L, Rivers C, Rothenbers BE. Genetic and clinical description of hemochromatosis probands and heterozygotes: evidence that multiple genes linked to the major histocompatibility complex are responsible for hemochromatosis. Blood Cells Mol Dis 1997;23:135-145.

169. McCune CA, Carter K, Worwood M, Ravine D, Jackson HA, Hutton D. The ancestral haplotype is not associated with an enhanced risk of developing iron overload in hereditary haemochromatosis: evidence from families studied in South Wales [abstract]. Gastroenterology 2004;126:A712.

170. Forsberg L, de Faire U, Morgenstern R. Oxidative stress, human genetic variation, and disease. Arch Biochem Biophys 2001;389:84-93.

171. Cerutti PA. Prooxidant states and tumor promotion. Science 1985;227:375-381.

172. De Freitas JM, Meneghini R. Iron and its sensitive balance in the cell. Mutat Res 2001;475:153-159.

173. Kelada SN, Eaton DL, Wang SS, Rothman NR, Khoury MJ. The role of genetic polymorphisms in environmental health. Environ Health Perspect 2003;111:10551064.

174. Anderson LM, Diwan BA, Fear NT, Roman E. Critical windows of exposure for children's health: cancer in human epidemiological studies and neoplasms in experimental animal models. Environ Health Perspect 2000;108:573-594. 